\section{A modified Phenol-chloroform extraction method for isolating circulating cell free DNA of tumor patients}

\author{
Hufnagl Clemens, Stöcher Markus, Moik \\ Martin, Geisberger Roland, Greil Richard \\ Third Medical Department with \\ Hematology, Medical Oncology, \\ Hemostaseology, Rheumatology and \\ Infectious Diseases Oncologic Center, \\ Laboratory of Immunological and \\ Molecular Cancer Research (LIMCR), \\ Center for Clinical Cancer and \\ Immunology Trials, Private Medical \\ University Hospital Salzburg, Austria
}

\begin{abstract}
Searching for new cancer biomarkers, circulating cell-free DNA (cfDNA) has become an appealing target of interest as an elevated level of cfDNA has been detected in the circulation of cancer patients in comparison with healthy controls. Since cfDNA can be isolated from the circulation and other body fluids of patients without harming their physical condition, cfDNA is becoming a promising candidate as a novel non-invasive biomarker for cancer. The challenge in the diagnostic analysis of cfDNA is its very low presence in human plasma/serum and its partially strong fragmentation. Here we evaluated a modified phenol/chloroform extraction method for the isolation of cfDNA and compared it with published standard methods for cfDNA isolation.
\end{abstract}

\section{Protocol}

Searching for new cancer biomarkers, circulating cell-free DNA (cfDNA) has become an appealing target of interest as an elevated level of cfDNA has been detected in the circulation of cancer patients in comparison with healthy controls. Since cfDNA can be isolated from the circulation and other body fluids of patients without harming their physical condition, cfDNA is becoming a promising candidate as a novel non-invasive biomarker for cancer. $^{1-3}$

The challenge in the diagnostic analysis of cfDNA is its very low presence in human plasma and its partially strong fragmentation. ${ }^{2}$

Here we evaluated a modified phenol/chloroform extraction method for the isolation of cfDNA in human plasma and compared it with published standard methods for cfDNA isolation. ${ }^{4}$ Although cfDNA was about 5-fold higher in serum samples compared to plasma (data not shown. ${ }^{5}$ We only show cfDNA levels determined from plasma samples which allows a better comparison with previously published protocols. ${ }^{6-8}$ Therefore, plasma samples from healthy individuals $(n=10)$ and patients with colon carcinoma $(\mathrm{n}=15)$ and breast cancer $(n=15)$ were analyzed in parallel using our modified phenol/chloroform method in comparison to the Maxwell ${ }^{\circledR} 16 \mathrm{LEV}$
Correspondence: Clemens Hufnagl, Third Medical Department with Hematology, Medical Oncology, Hemostaseology, Rheumatology and Infectious Diseases Oncologic Center, Laboratory of Immunological and Molecular Cancer Research (LIMCR), Center for Clinical Cancer and Immunology Trials, Private Medica University Hospital Salzburg, Austria.

Fax: +43.662 .44823468$

E-mail: cl.hufnagl@salk.at

Key words: cell-free DNA.

Contributions: $\mathrm{HC}$, wrote the manuscript and did the primary research; GR, advice, guidance and support and assistance in preparing the manuscript; SM, MM, GR, advice, guidance and support.

Conflict of interests: the authors declare no potential conflict of interests.

Received for publication: 26 April 2012.

Revision received: 11 July 2012.

Accepted for publication: 13 July 2012.

This work is licensed under a Creative Commons Attribution NonCommercial 3.0 License (CC BYNC 3.0).

(C) Copyright H. Clemens et al., 2013

Licensee PAGEPress, Italy

Journal of Nucleic Acids Investigation 2013; 4:e1 doi:10.4081/jnai.2013.el

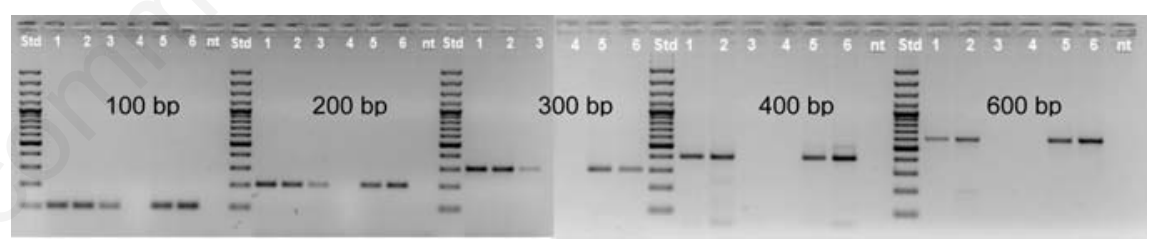

Figure 1. Control gene PCR for the assessment of amplifiability and integrity of DNA samples. Five control genes exons and the five primer sets for obtaining PCR products of $100,200,300,400$, and $600 \mathrm{bp}^{9} .100 \mathrm{bp}$ ladder marker, samples from cancer patients 1-4; healthy controls 5, 6 and no template control, primer used as described in van Dongen $e t$ al. 2003.

Table 1. Results obtained by real-time PCR quantification of cfDNA, using hTERT obtained from $1 \mathrm{~mL}$ of plasma, respectively (mean \pm std. error).

\begin{tabular}{|c|c|c|c|}
\hline Methods & $\begin{array}{l}\text { Healthy individuals } \\
\text { pg/jL }\end{array}$ & $\begin{array}{l}\text { Patients with carcinoma } \\
\mathrm{pg} / \mathrm{\mu L}\end{array}$ & P value \\
\hline Maxwell ${ }^{\circledR} 16$ LEV DNA Purification Kit & $0.89 \pm 0.33$ & nd & 0.0001 \\
\hline QIAamp ${ }^{\circledR}$ DNA Mini and Blood Mini kit & $1.22 \pm 0.80$ & nd $\left(13-309^{*}\right)$ & 0.0001 \\
\hline NucleoSpin ${ }^{\circledR}$ Plasma XS8 & $1.87 \pm 0.99$ & nd $\left(10-423^{*}\right)$ & 0.0001 \\
\hline Modified Phenol-chloroform extraction & $86.91 \pm 13.04$ & $755.4 \pm 199.6$ & \\
\hline Phenol-chloroform extraction by Schmidt et al. ${ }^{6}$ & $23.78 \pm 3.91$ & $190.3 \pm 52.14$ & $\begin{array}{c}0.008 \\
\text { (healthy) } \\
0.035 \text { (carcinoma) }\end{array}$ \\
\hline
\end{tabular}

P-values indicate significance of results in comparison to the modified phenol-chloroform extraction. (nd: not determined). *Data according to publications; Silva et al. 2002, Stemmer et al. 2003, Xie et al. 2004, Lui et al. 2001, Lecomte et al. 2002, Gal et al. 2004, Gautschi et al. 2004, Di et al. 2003, Ito et al. 2003. 
DNA Purification Kit (Promega), QIAamp ${ }^{\circledR}$ DNA Mini and Blood Mini kit (Qiagen), NucleoSpin ${ }^{\circledR}$ Plasma XS (Macherey-Nagel) ${ }^{8}$ and a published Phenol-chloroform extraction method. ${ }^{6}$

The samples were processed to obtain plasma within an hour after the withdrawal of blood from donors. The plasma was obtained by two centrifugations of whole blood EDTA-tubes

Table 2. Control gene PCR for the assessment of amplifiability and integrity of DNA samples. Five control genes exons and the five primer sets for obtaining PCR products of $100,200,300,400$, and $600 \mathrm{bp}^{9}$. PCR positive number of patients in comparison to total number of samples for controls and patients set in parentheses.

\begin{tabular}{lcc} 
& $\begin{array}{c}\text { PCR product } \\
\text { control samples }\end{array}$ & $\begin{array}{c}\text { PCR positive } \\
\text { PCR positive patient samples }\end{array}$ \\
$100 \mathrm{bp}$ & $10(10)$ & $27(30)$ \\
$200 \mathrm{bp}$ & $10(10)$ & $26(30)$ \\
\hline $300 \mathrm{bp}$ & $10(10)$ & $24(30)$ \\
$400 \mathrm{bp}$ & $10(10)$ & $23(30)$ \\
\hline $600 \mathrm{bp}$ & $10(10)$ & $21(30)$ \\
\hline
\end{tabular}
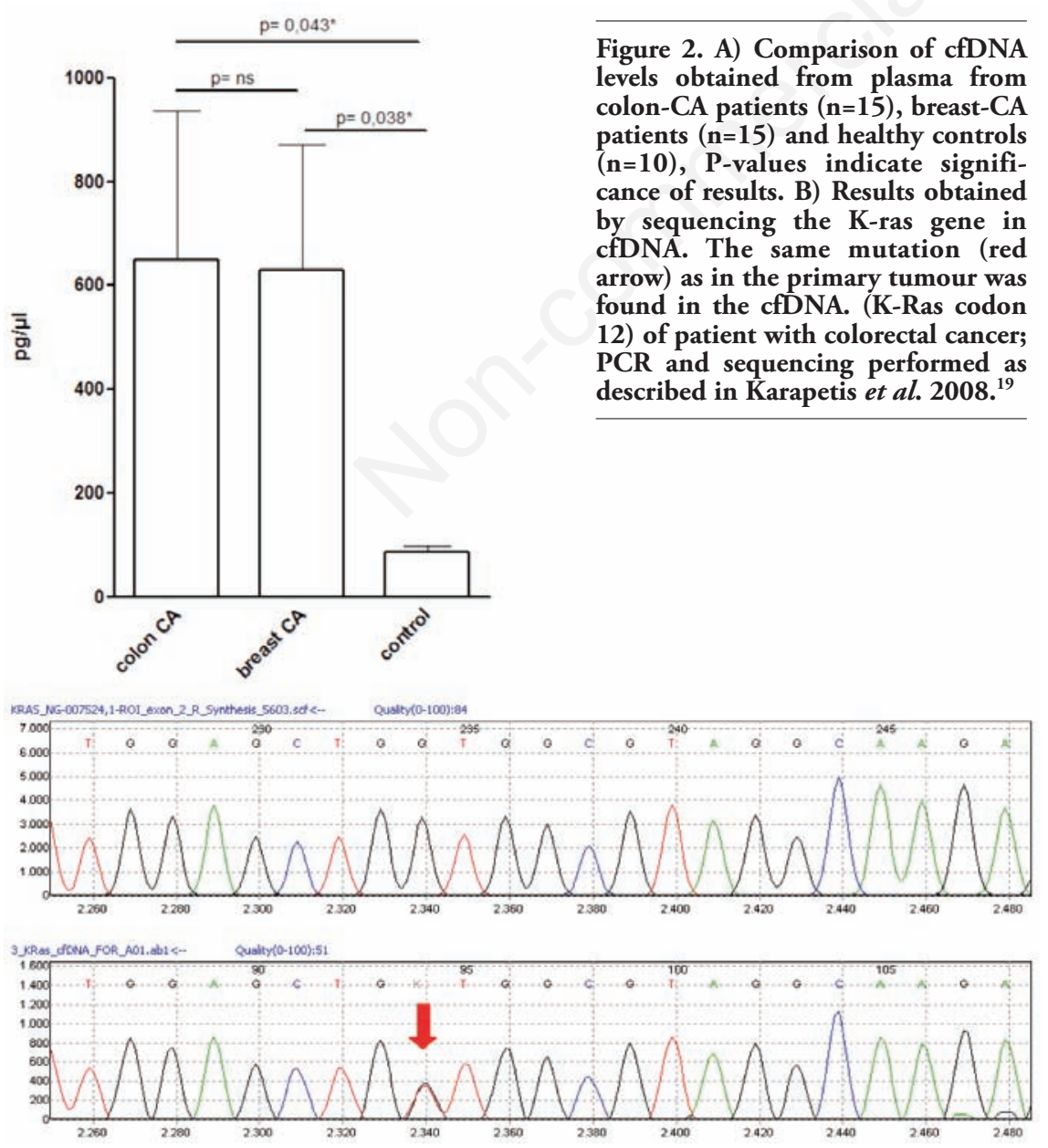

tion (final concentration, $0.86 \mathrm{~mol} / \mathrm{L}$ ). The cfDNA was extracted with a 1:1 phenol-chloroform mixture at room-temperature. After incubation time of $5 \mathrm{~min}$ at room temperature the solution was centrifuged for $15 \mathrm{~min}$ at 14,000 g. The cleared supernatant was transferred into a new tube and the DNA was precipitated by adding the same volume of absolute ethanol and incubating overnight at $-20^{\circ} \mathrm{C}$. The DNA was first centrifuged for $15 \mathrm{~min}$ at 14,000 g, then washed with $70 \%$ ethanol and dissolved in $50 \mu \mathrm{L}$ water. We used $5 \mu \mathrm{L}$ of template DNA for quantification, and each sample was analyzed in duplicate. The DNA was quantified by a real-time PCR analysis using the sequence of hTERT, the human telomerase reverse transcriptase. ${ }^{7}$ The amplicon size of the hTERT single copy gene was 98 bp. As shown in Table 1, our modified cfDNA extraction method was superior to all tested kit-based standard extraction methods and led also to a DNA yield which was about four times higher compared to the recently published method by Schmidt et al., ${ }^{6}$ which is similar to our presented protocol. However, Schmidt et al describe the isolation of cfDNA within 2 working days, whereupon we decided to set up a protocol aiming at completing cfDNA purification within only one working day. To achieve this, we performed a single DNA precipitation, whereas Schmidt et al performed two consecutive rounds of precipitations. As DNA gets lost with every round of precipitation, omitting the second precipitation step may at least in part explain the higher amount of cfDNA gained by our protocol. In addition, the slightly different salt concentration used for cfDNA precipitation may also account for the higher efficiency of our method.

Regarding the fragment-length of the isolated cell free DNA we were able to detect fragments from $100 \mathrm{pb}$ up to $600 \mathrm{bp}$ via PCR, ${ }^{9}$ isolated with all methods but noticed a higher fragmentation of cfDNA in patients compared to healthy controls (Figure 1 and Table 2). ${ }^{10}$

However, the presence of sequences shorter than 98 bp as early marker for the attendance of tumors was not examinated in this study (Moulière et al. personal communication).

Regarding the clinical aspects we were able to detect tumor-specific mutations (KRAS codon $12-13$ and BRAF V600E point mutations $)^{11-14}$ and we found significantly increased levels of cell-free DNA in patients compared to controls, which is in line with former published data (Figures 2 and 3). ${ }^{3,15-20}$ In summary, we were able to show a simple and robust method for extraction, isolation and analysis of cfDNA, suitable for a routine clinical-oncology laboratory. In addition, this method was suitable for further PCR-based characterization sequencing applications. 


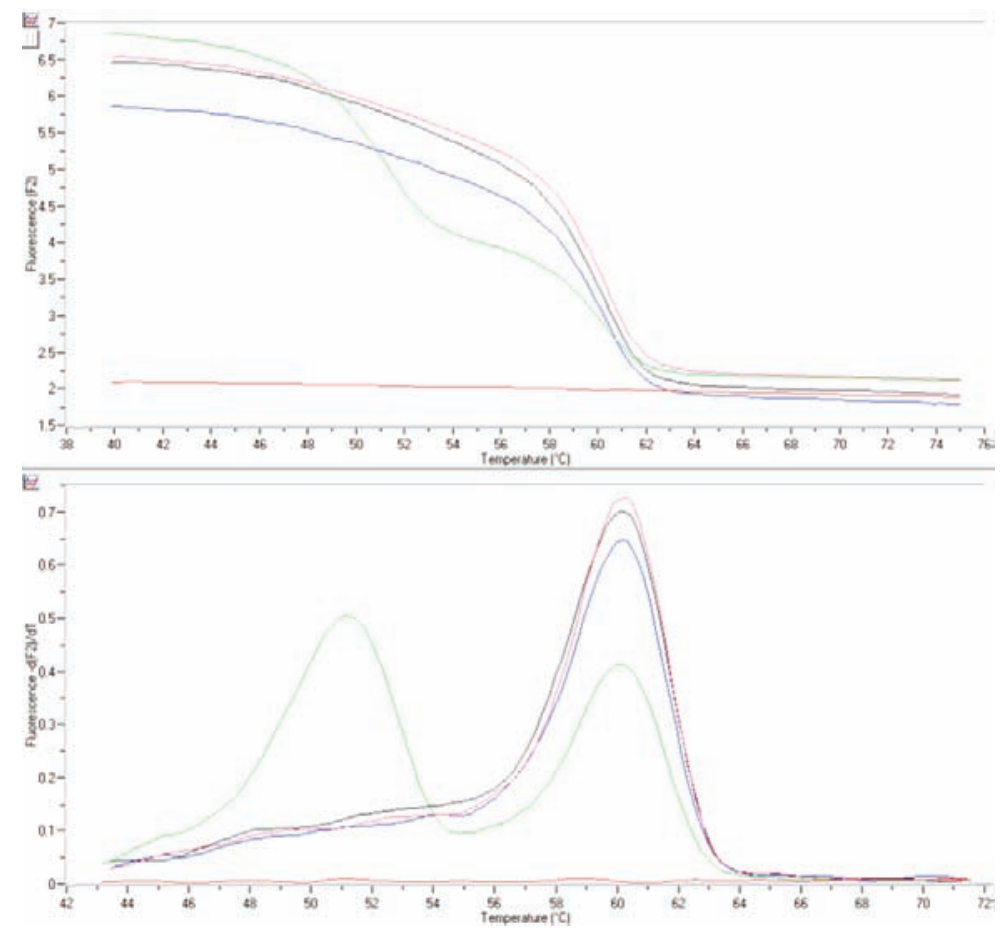

Figure 3. Results obtained by real-time PCR of B-Raf V600E point mutation in cfDNA of patient with breast cancer (same mutation in primary tumour). Melting curve analysis of a B-Raf V600E-mutated patient (green graph) with hybridization probe, PCR and detection method performed as described in Nikiforova et al 2003. ${ }^{20}$

\section{References}

1. Kohler C, Barekati Z, Radpour R, Zhong $\mathrm{XY}$. Cell-free DNA in the circulation as a potential cancer biomarker. Anticancer Res 2011;31:2623-8.

2. Jung K, Fleischhacker M, Rabien A. Cellfree DNA in the blood as a solid tumor biomarker - a critical appraisal of the literature. Clin Chim Acta 2010;411:1611-24.

3. Fleischhacker M, Schmidt B. Circulating nucleic acids (CNAs) and cancer - a survey. Biochim Biophys Acta 2006;1775:181232

4. Fleischhacker M, Schmidt B, Weickmann $\mathrm{S}$, et al. Methods for isolation of cell-free plasma DNA strongly affect DNA yield. Clin Chim Acta 2011;412:2085-8.

5. Umetani N, Hiramatsu S, Hoon DS. Higher amount of free circulating DNA in serum than in plasma is not mainly caused by contaminated extraneous DNA during separation. Ann NY Acad Sci 2006;1075:299-
307.

6. Schmidt B, Weickmann S, Witt C, Fleischhacker M. Improved method for isolating cell-free DNA. Clin Chem 2005;51:1561-3.

7. Paci M, Maramotti S, Bellesia E, et al. Circulating plasma DNA as diagnostic biomarker in non-small cell lung cancer. Lung Cancer 2009;64:92-7.

8. Kirsch C, Weickmann S, Schmidt B, Fleischhacker M. An improved method for the isolation of free-circulating plasma DNA and cell-free DNA from other body fluids. Ann NY Acad Sci 2008;1137:135-9.

9. van Dongen JJ, Langerak AW, Brüggemann $M$, et al. Design and standardization of PCR primers and protocols for detection of clonal immunoglobulin and T-cell receptor gene recombinations in suspect lymphoproliferations: report of the BIOMED-2 Concerted Action BMH4-CT98-3936. Leukemia 2003;17:2257-317.

10. Jahr S, Hentze H, Englisch S, et al. DNA fragments in the blood plasma of cancer patients: quantitations and evidence for their origin from apoptotic and necrotic cells. Cancer Res 2001;61:1659-65.

11. Dabritz J, Hanfler J, Preston R, et al. Detection of Ki-ras mutations in tissue and plasma samples of patients with pancreatic cancer using PNA-mediated PCR clamping and hybridisation probes. $\mathrm{Br} \mathrm{J}$ Cancer 2005;92:405-12.

12. García-Olmo DC, Domínguez C, GarcíaArranz M, et al. Cell-free nucleic acids circulating in the plasma of colorectal cancer patients induce the oncogenic transformation of susceptible cultured cells. Cancer Res 2010;70:560-7.

13. Davies H, Bignell GR, Cox C, et al. Mutations of the BRAF gene in human cancer. Nature 2002;417:949-54.

14. Pinzani P, Salvianti F, Cascella R, et al. Allele specific Taqman-based real-time PCR assay to quantify circulating BRAFV600E mutated DNA in plasma of melanoma patients. Clin Chim Acta 2010; 411:1319-24.

15. Sirera R, Bremnes RM, Cabrera A, et al. Circulating DNA is a useful prognostic factor in patients with advanced non-small cell lung cancer. J Thorac Oncol 2011;6: 286-90.

16. Gormally E, Caboux E, Vineis $P$, Hainaut $P$. Circulating free DNA in plasma or serum as biomarker of carcinogenesis: practical aspects and biological significance. Mutat Res 2007;635:105-17.

17. Anker P, Stroun M. Circulating DNA in plasma or serum. Medicina (B Aires) 2000; 60:699-702.

18. Anker P, Mulcahy H, Chen XQ, Stroun M. Detection of circulating tumour DNA in the blood (plasma/serum) of cancer patients. Cancer Metastasis Rev 1999;18: 65-73.

19. Karapetis CS, Khambata-Ford S, Jonker DJ, et al. K-ras mutations and benefit from cetuximab in advanced colorectal cancer. N Engl J Med 2008;359:1757-65.

20. Nikiforova MN, Kimura ET, Gandhi M, et al. BRAF mutations in thyroid tumors are restricted to papillary carcinomas and anaplastic or poorly differentiated carcinomas arising from papillary carcinomas. $\mathrm{J}$ Clin Endocrinol Metab 2003;88:5399-404. 